Available online:

IMLA http://journal.imla.or.id/index.php/arabi

Arabi : Journal of Arabic Studies, 1 (2), 2016, 75-89

\title{
ANALISIS KISAH NABI YUSUF DALAM AL-QURAN MELALUI PENDEKATAN INTERDISIPLINER PSIKOLOGI SASTRA
}

\author{
Hanik Mahliatussikah \\ Universitas Negeri Malang \\ E-mail : hanik.mahliatussikah.fs@um.ac.id
}

\begin{abstract}
The emergence of psycho-literature study is in line with the relation between psychology and literature. Psychoanalysis theory used in this study was the theory of Sigmund Freud to examine the character of Yusuf. This theory distinguished three kinds of personality; they are id, ego, and superego. This research investigated Yusuf's behavior in the context of citizenship. The story of Yusuf is determined as the best story from the aspect of its styles, contents, and objectives. This story was begun with the dream of Yusuf, sunk into the well, sold to Egyptian merchant, flirted by the wife of his merchant, found by his family, and the lessons of his story. In its relation to Islam, superego in the theory of Freud should be aimed to Islamic values. The principle of tauhid should always be in mind, so when bed desire comes to a moslem, then that principle will be the savior. Psycho-literature interdisciplinary study uncovers psychological aspects of Yusuf to take the lessons for the society.
\end{abstract}

Keywords: prophet Yusuf, Al-Quran, psychology, literature

\begin{abstract}
Abstrak
Munculnya kajian psikologi sastra tidak terlepas dari pertautan antara ilmu psikologi dan sastra. Teori psikoanalisa yang digunakan adalah teori Sigmund Freud untuk mengkaji tokoh Yusuf. Teori ini membedakan kepribadian menjadi 3, yaitu id, ego, dan Superego. Penelitian in mengkaji tingkah laku tokoh Yusuf yang dipahami dalam arti keseluruhan dimana ia menjadi anggota suatu masyarakat. Kisah Yusuf merupakan kisah yang terbaik (ahsanul Qashash) dari aspek gaya, kandungan, dan tujuannya. Kisah ini diawali dengan mimpi Yusuf, disingkirkan kedalam sumur, dijual kepada saudagar Mesir, dirayu istri tuannya, jamuan makan, dipenjara, menakwilkan mimpi, dipertemukan keluarganya, dan itibar dari kisah Yusuf. Dalam kaitannya dengan Islam, superego dalam teori Freud hendaknya diarahkan pada nilai-nilai Islam. Prinsip tauhid harus dipegang sehingga ketika hasrat berbuat buruk muncul dalam diri seorang muslim, maka prinsip tauhid tersebut akan mampu menjadi bentengnya. Kajian interdisipliner psikologi sastra mampu mengungkap sisi-sisi psikologis tokohYusuf yang dapat dijadikan pelajaran penting bagi umat manusia.
\end{abstract}

Kata Kunci: nabi yusuf, al-Quran, psikologi, sastra 


\section{Arabi : Journal of Arabic Studies}

\section{Pendahuluan}

Menurut Jakobson, tidak ada kesempurnaan teori dan metodologi apapun. Masalah-masalah sensitif dalam kehidupan manusia banyak yang tidak dapat diatasi dan diselesaikan dengan ilmuilmu disipliner yang spesialis dan partikular. Watak idiologis dan subjektivitas ilmu-ilmu disipliner banyak yang tidak dapat dimanfaatkan secara pasti dalam konteks kebutuhan masyarakat (Sudikan, 2015: 7; Saryono, 2015). Karena itulah, dibutuhkan pertemuan antara berbagai bidang ilmu untuk menyelesaikan masalah tertentu secara komprehensif. Interdisipliner merupakan interaksi intensif antar satu atau lebih disiplin ilmu, baik yang langsung berhubungan atau yang tidak, melalui program-program penelitian, dengan tujuan melakukan integrasi konsep, metode, dan analisis (Prentice, 1990). Pendekatan interdisipliner (interdisciplinary approach) yang muncul pada abat ke-XX berarti pendekatan yang menyarankan penelitian dengan melibatkan dua bidang ilmu atau lebih.

Bahasa Al-Quran merupakan alat interaksi verbal yang dapat dikaji, baik secara internal maupun eksternal. Kajian internal berkait an dengan struktur fonologi, morfologi, sintaksis, sampai struktur wacana. Adapun kajian eksternal terhadap bahasa Al-Quran berkaitan dengan hubungan bahasa itu dengan foktor-faktor di luar bahasa, seperti sosiologi, antropologi, dan psikologi. Dengan demikian, kajian psikologi sastra termasuk kajian ekstrinsik, sebagai makro sastra dan interdisipliner. Tuntutan kebutuhan dalam kehidupan menyebabkan pentingnya kajian interdisipliner, yaitu kajian bersama antara dua disiplin ilmu atau lebih.

Kisah Nabi Yusuf dalam perspektif psikologis mengandung pelajaran berharga, utamanya psikologi tokoh, baik tokoh Nabi Yusuf selaku tokoh primer, maupun tokoh-tokoh sekunder yang lain. Perilaku para tokoh dalam surat Yusuf mencerminkan watak dan mental masyarakat pada waktu itu. Bagaimana pun, sebuah teks, dalam hal ini Al-Quran tidak diturunkan dalam kekosongan budaya (Wolf, 1989). Kisah Nabi Yusuf dalam Al Quran merupakan gambaran realitas kehidupan sosial masyarakat yang berlaku pada saat itu (Akrom, 2014: 234).

Al-Quran menggunakan bahasa Sastra yang tinggi. Yang membedakan Al-Quran dengan teks sastra adalah adanya unsur fiktif pada penciptaan teks Sastra dan unsur kebenaran mutlak pada teks wahyu sebagai kalamullah. Kisah termasuk dalam bahasan sastra dan dalam setiap kisah mengandung pelajaran berharga. Kisah Nabi Yusuf tidak hanya sebagai pelajaran bagi masyarakatnya, tetapi juga bagi umat di masa kini. Tokoh Nabi Ya'kub dan Nabi Yusuf adalah cermin seorang ayah dan anak yang saling menyayangi, dan penyabar dalam menghadapi berbagai ujian dan musibah. Allah tidak akan membebankan musibah yang melebihi kadar kemampuan seorang hamba. Nabi Yusuf seorang yang berbakti kepada Allah dan ayahnya, menyayangi saudaranya, dan selalu menjaga diri dari perbuatan mungkar, serta selalu menolong orang-orang yang membutuhkan pertolongan. Ia mendapatkan pahala berupa kedudukan mulia dalam pemerintahan di Mesir. Perbuatan baik dibalas dengan kebaikan yang berlipat, sedangkan perbuatan jahat dibalas dengan semisalnya.

\section{Psikoanalisis Sigmund Freud}

Menurut Freud, asas psikologi adalah alam bawah sadar, yang disadari secara samar-samar oleh individu yang bersangkutan. Menurut Freud, ketaksadaran justru merupakan bagian yang paling besar dan paling aktif dalam diri setiap orang. Adapun kesadaran merupakan bagian kecil saja dari kehidupan mental. Dalam teori Freud, manusia memiliki 2 lapis ketaksadaran, yaitu ketaksadaran personal dan ketaksadaran kolektif. Isi ketaksadaran personal diterima melalui pengalaman kehidupan sebagai material ontogenesis. Adapun ketaksadaran kolektif diterima secara universal dan esensial, sebagai pola-pola behavioral, sebagai material filogenesis. Bentuk ketaksadaran kolektif juga disebut arketipe, yang pada umumnya disamakan primordial.

Dalam psikoanalisis, kepribadian manusia dibagi 3, yaitu id, ego, dan superego. Tingkah laku manusia merupakan produk interaksi ketiganya (Endraswara, 2003: 101). 


\section{Id}

Id adalah sistem kepribadian manusia yang paling dasar. Ia merupakan aspek bawah sadar manusia yang berisi sifat-sifat keturunan, insting dan nafsu (kenikmatan) yang tak kenal nilai. Id cenderung menghendaki penyaluran untuk setiap keinginan dan jika terhalangi akan terjadi ketegangan. Id merupakan prinsip kesenangan dan kenikmatan (the pleasure principle) dan ia akan mengejawantahkan penyalurannya dengan jalan irasional, tanpa mempertimbangkan akibat atau konsekuensi. Watak ini tidak mengenal rasa takut dan cemas sehingga tidak memiliki tindakan hati-hati dalam upaya penyaluran hasrat (Endraswara, 2003: 101; Siswantoro, 2005: 38-39;max, 1992).

Untuk mencapai maksud dan tujuannya itu, id memiliki dua macam proses, yaitu proses tindakan-tindakan refleks dan proses primer. Tindakan refleks yaitu bentuk tindakan yang mekanisme kerjanya otomatis dan segera. Adapun proses primer adalah suatu proses yang melibatkan sejumlah reaksi psikologis yang rumit. Tindakan memuaskan suatu kebutuhan yang berlangsung dalam mimpi oleh Freud juga dipandang sebagai proses primer (Kuswara, 1991: 33).

Id merupakan gudang tempat menyimpan semua insting. Ia sudah ada sejak manusia dilahirkan. Pada mulanya, semua energi psikis disalurkan ke id untuk memenuhi kebutuhankebutuhan yang memang harus dipenuhi untuk kelangsungan diri. Energi id dikendalikan sepenuhnya oleh prinsip kenikmatan ini. Energi id berada dalam keadaan bebas tanpa kekangan apapun dan tidak bisa membedakan antara yang nyata dan tidak nyata. Pemikiran yang tidak membedakan antara khayalan dan kenyataan ini disebut pemikiran proses primer (primary process thinking). Energi psikis yang terkait dengan id bersifat bawah sadar, karena hal itu tidak disadari oleh individu dan tidak bisa ia bicarakan atau pikirkan (Salkind, t.t.: 158).

Semua energi psikis yang terkait dengan id tidak ada padanan verbalnya; tidak tertangkap oleh proses-proses mental yang lebih tinggi; emosi dan perasaan yang terkait dengannya tidak bisa dipikirkan di atas landasan rasional. Alam bawah sadar mendorong agar id tetap aktif sepanjang hidup, tetapi apabila individu bertambah dewasa maka kadar energi psikis yang didistribusikan kepada id semakin sedikit. Kadar energi psikis yang didistribusikan kepada ego dan superego kemudian bertambah banyak.

\section{Ego}

Ego merupakan perilaku yang didasarkan pada prinsip kenyataan. Ego merupakan sistem kepribadian yang bertindak sebagai pengarah individu kepada dunia objek nyata dan menjalankan fungsinya berdasarkan kenyataan. Ego adalah kepribadian implementatif, yang terjadi akibat kontak dengan dunia luar. Ego seseorang mulai berkembang karena ketidakmampuan id untuk memenuhi sendiri semua kebutuhan individu. Ia perlu interaksi dengan lingkungannya dalam rangka identifikasi. Pada tahap ini, organisme bisa membedakan antara fantasi dan kenyataan. Proses yang dimiliki dan dijalankan ego sehubungan dengan upaya memuaskan kebutuhan disebut proses sekunder (secondary process thinking) (Salkind, $\mathrm{tt}$ : 158). Dengan proses sekunder ini, ego akan berfikir dengan melibatkan fungsi kognitifnya untuk menentukan apakah akan melaksanakan pemuasan kebutuhan tersebut atau tidak (Koswara, 1991: 34). Ego pada awalnya berupa ego penikmat kemudian meningkat menjadi ego rasional yang dikendalikan oleh prinsip realitas. Kenikmatan ego diwujudkan dengan cara mematuhi realitas-realitas eksternal.

Selain berfungsi sebagai pertimbangan realistis terhadap lingkungan, ego menjalankan fungsi penting lainnya yaitu sebagai penengah antara id dan superego dan mengendalikan arah energi yang tersalur ke dunia luar. Menurut Freud, persepsi indrawi lebih banyak pengaruhnya pada ego dibandingkan pada id dan superego. Pentingnya pengalaman-pengalaman sensorimotor pada ego seperti pentingnya insting pada id. Ego berfungsi sebagai mekanisme pengambilan keputusan yang bertindak sesuai dengan keinginan bawah sadar id. Ego bertugas sebagai pelaksana. Ego adalah perantara yang mengurusi energi yang tersedia dan mengatur pengeluaran energi dalam 


\section{Arabi : Journal of Arabic Studies}

keseluruhan sistem untuk memastikan terpenuhinya kebutuhan dan juga terpeliharanya jumlah energi bagi pertumbuhan selanjutnya.

\section{Superego}

Superego berkembang mengontrol perilaku yang ditimbulkan oleh id. Superego merupakan sistem kepribadian yang berisi nilai-nilai dan aturan yang bersifat evaluatif, menyangkut baikburuk (Endraswara, 2003 :101; Milner, 1992:43). Menurut Freud, energi psikis yang terkait dengan superego terdiri atas ego ideal dan kesadaran nurani. Ego ideal berwujud penilaian tertentu, yang secara moral dipandang baik. Adapun hati nurani berwujud hal-hal yang secara moral dipandang baik.

Apabila id mendorong organisme ke arah pemenuhan kebutuhan, ego mengusahakan pemenuhan kebutuhan itu melalui interaksi konstruktif dengan lingkungan, maka superego bertindak sebagai energi psikis yang menjadi kekuatan penghalang id agar tidak mengekspresikan dorongan-dorongan yang tidak tepat menurut standar norma yang berlaku di masyarakat. Superego juga mendorong agar individu mengusahakan apa yang ideal.

Superego merupakan sistem kepribadian yang berisikan nilai-nilai dan aturan-aturan yang sifatnya evaluatif. Fungsi utama superego adalah (a) pengendali dorongan-dorongan naluri id agar disalurkan dalambentuk yang bisa diterima di masyarakat, (b) mengarahkan ego pada tujuantujuan yang sesuai dengan moral dibanding dengan kenyataan, dan (c) mendorong individu kepada kesempurnaan (Koswara, 1991: 34-35). Id, ego, dan superego itu hendaknya berjalan seimbang. Jika tidak, akan menimbulkan neurosis dalam diri manusia.

Dalam Islam juga dikenal 3 tingkatan nafsu, yaitu an-nafs al-ammârah, an-nafs al-lawwâmah dan an-nafs al-muthmainnah. An-nafs al-ammârah merupakan nafsu yang selalu mendorong pemiliknya kepada perbuatan yang buruk. An-nafs al-lawwâmah merupakan nafsu yang selalu mengecam pemiliknya setiap kali berbuat kesalahan, sehingga timbul penyesalan dan berjanji untuk tidak mengulangi kesalahan. Adapun an nafs al-muthmainnah adalah jiwa yang tenang karena selalu mengingat Allah dan jauh dari segala pelanggaran dan dosa.

\section{Teori Mimpi: Konsep Sigmund Freud dan Konsep Islam}

Tidak ada definisi yang diterima secara universal mengenai mimpi. Dalam American Heritage Dictionary (2000), mimpi adalah deretan pemikiran, citra, suara, atau emosi yang dialami pikiran saat tidur. Menurut Freud, mimpi merupakan produk psikis dan karena hidup psikis dianggap sebagai konflik antara daya-daya psikis. Mimpi mempunyai struktur yang sama dengan gejala neurotis, sehingga dengan cara ini, orang dapat mempelajari represi dan mekanisme tak sadar lainnya. Dalam psikoanalisa, mimpi lebih menguntungkan dibanding gejala neurotis, karena mimpi dialami secara tidak sadar pada waktu tidur. Mimpi merupakan keinginan tak sadar yang muncul dalam kesadaran. Mimpi merupakan perealisasian suatu keinginan yang terpendam (Bertens, 1984:xxv). Mimpi adalah penghubung antara kondisi bangun dan tidur.

Pada tahun 1976, J. Allan Hobson dan Robert McCarley mengajukan sebuah teori baru yang bernama teori sintesis aktivasi yang merubah penelitian mimpi, menantang pandangan mimpi Freud sebelumnya yang menyatakan bahwa mimpi merupakan keinginan bawah sadar untuk ditafsirkan (Error! Hyperlink reference not valid.. diakses 6 Mei 2016 ). Menurut mereka, otak depan yang teraktivasi mensintesa mimpi dari informasi yang dibuatnya secara internal. Sinyal yang ditafsirkan sebagai mimpi berasal dari batang otak saat tidur dengan gerakan mata cepat (Rapid eye MovementREM). Adapun menurut Jie Zhang, mimpi merupakan hasil dari aktivasi dan sintesis otak pada saat bersamaan, tidur REM dan mimpi dikendalikan oleh mekanisme otak yang berbeda. Inilah yang disebut dengan teori aktivasi berkelanjutan. Mimpi memiliki karakteristik kontinuitas dan perubahan mendadak (Zhang, 2005).

Eugen Tarnow (2003) menyatakan bahwa mimpi merupakan perangsang ingatan jangka panjang yang selalu ada dan bahkan saat sadar. Ini senada dengan Freud yang menyatakan bahwa 
ketaksadaran digantikan dengan sistem ingatan jangka panjang. Adapun menurut Coutts (2008), mimpi itu memodifikasi dan menguji skema mental sat tidur dalam sebuah proses seleksi emosional. Arthur Schopenhauer mengatakan bahwa sebuah mimpi adalah psikosis jangka pendek, dan sebuah psikosi adalah mimpi jangka panjang. Freud (1940) juga menyatakan bahwa mimpi adalah sebuah psikosis. Biarpun dalam keadaan tidur, represi pihak ego tidak terhapus. Mimpi adalah cara berkedok untuk mewujudkan keinginan yang direpresi. Hal ini karena keinginan dan hasrat itu mencari akal untuk untuk menipu sensur, yaitu dengan mengubah bentuknya (berkedok). Pada waktu tidur keinginan yang direpresi tidak dapat lolos dari sensur. Kalau keinginan dan hasrat terlalu kuat, maka sensur kewalahan dan orang yang tidur diganggu mimpi cemas.

Bagi Freud, untuk menafsirkan mimpi, seseorang harus menelusuri proses terbentuknya mimpi dalam jurusan yang berlawanan. Dengan bertolak pada mimpi yang terang, orang harus kembali ke pikiran-pikiran yang tersembunyi yang telah didistorsi oleh sensur, setelah melewati berbagai distorsi, akhirnya orang dapat memperlihatkan keinginan yang direpresi (Bertens, 1984:xxvi).

Adapun dalam konsep Islam, mimpi baik berasal dari Allah dan mimpi buruk berasal dari syetan. Al Quran banyak menyebut kisah mimpi para nabi yang merupakan mimpi yang benar, baik terkait dengan hal yang sudah terjadi maupun yang akan dialami. Peristiwa mimpi dan pentakwilannya dalam Al Quran terdapat dalam surat Yusuf ayat 4-5, 36-37, 100; al-Isra' ayat 60, ash-Shaffat ayat 102-107 dan al-Fath ayat 27.

Mimpi ada yang benar dan terjadi sebagaimana mimpi para nabi. Mimpi yang benar ini merupakan petunjuk dari Allah SWT. Mimpi yang benar itu ada kalanya transparan sebagaimana mimpinya nabi Ibrahim untuk menyembelih anaknya. Ada pula yang tersamar seperti mimpi Nabi Yusuf melihat sebelas bintang dan bulan yang bersujud kepadanya. Adapun mimpi yang baik, tetapi tidak terjadi misalnya mimpi bertemu orang-orang saleh. Ada pula mimpi simbolis yang dapat ditafsirkan dengan berbagai penafsiran. Terkadang ada mimpi yang menakutkan dalam rangka mengingatkan adanya bahaya atau musibah yang akan terjadi. Ada pula mimpi yang mungkin benar adalah mimpi yang terkait dengan peristiwa yang dipikirkan dan dialami keseharian. Mimpi bisa saja tidak bermakna akibat bagian-bagian mimpi itu yang terpenggalpenggal dan tidak dapat dipahami.

Menurut Ibnu Arabi, mimpi merupakan bagian dari imajinasi. Menurutnya, mimpi ada 3 macam, yaitu pertama mimpi atau kesan-kesan yang berhubungan dengan kegiatan keseharian atau cermin kegiatan keseharian. Kedua, mimpi yang berupa simbol yang masih harus ditafsirkan. Menurut Freud, simbolisme merupakan bagian paling mengagumkan dalam teorinya. Ketiga, mimpi spiritual non simbolik, imajinasi tidak campur tangan, hati langsung merefleksikan kesankesan spiritul (maâni ghaibiyah). Ini diperoleh oleh jiwa-jiwa yang telah mengalami penyucian hati sehingga mencapai tarafnya para wali dan nabi (Ghazali, 2006).

Terkait dengan etika orang yang bermimpi, Rasulullah Bersabda: "Orang yang paling benar ucapannya, maka paling benar pula mimpinya". Sebaiknya sebelum tidur, dilakukan wudhu terlebih dahulu, kemudian berdoa sebagaimana doa Aisyah "Aku memohon kepada-Mu mimpi yang baik, benar, tidak dusta, bermanfaat, tidak membahayakan, dan dapat diingat serta tidak lupa". Rasulullah melarang umatnya berdusta tentang mimpi, sebagaimana sabdanya "Barang siapa yang berdusta tentang mimpinya, maka pada hari Kiamat Allah akan menyuruhnya mengikatkan gandum dan ia tidak mampu melakukannya (Sirin, 2004: ix-xvii).

\section{Kajian Psikologi Sastra}

Adkinson menjelaskan bahwa psikologi merupakan ilmu pengetahuan yang mempelajari perilaku dan proses mental (study of behavior and mental processes). Senada dengan pengertian itu, Muhibbin menyatakan bahwa psikologi merupakan ilmu pengetahuan yang menyelidiki dan membahas tingkah laku manusia, baik yang terbuka seperti duduk dan berjalan maupun yang 


\section{Arabi : Journal of Arabic Studies}

tertutup seperti berpikir dan berbahasa. Ilmu pengetahuan yang membahas tentang penghayatan tingkah laku manusia sebagai makhluk individu dan penghayatan terhadap intern relasi manusia terhadap diri dan lingkungannya sebagai makhluk sosial beserta implikasi-implikasi lainnya itulah yang disebut dengan psikologi (Nursalim, 2007: 1-2; Chaer, 2009:2; Siswantoro, 2005: 26).

Dalam perkembangannya, psikologi terbagi menjadi 3 aliran sesuai paham filsafat, yaitu psikologi mentalistik yang melahirkan aliran psikologi kesadaran, psikologi behavioristik yang melahirkan psikologi perilaku, dan psikologi kognifistik yang melahirkan psikologi kognitif. Psikologi kesadaran mengkaji proses-proses akal manusia dengan cara mengintrospeksi, suatu proses akal dengan cara melihat ke dalam diri sendiri setelah suatu rangsangan terjadi. Psikologi perilaku mengkaji perilaku manusia yang berupa reaksi apabila suatu rangsangan terjadi dan selanjutnya bagaimana mengontrol dan mengawasi perilaku itu. Adapun yang dikaji dalam psikologi kognitif adalah bagaimana cara manusia memperoleh, menafsirkan, mengatur, mengeluarkan, dan menggunakan pengetahuan tanpa harus ada rangsangan terlebih dahulu (Chaer, 2009: 3). Karena psikologi berkaitan erat dengan berbagai masalah kehidupan manusia, kemudian muncullah berbagai cabang psikologi sesuai dengan penerapannya, seperti psikologi komunikasi, psikologi anak, psikologi bahasa, dan psikologi sastra.

Adapun yang dimaksud dengan kajian psikologi sastra bukanlah kajian terhadap teks yang ditinjau dari 2 aspek; psikologi dan sastra, melainkan kajian psikologi terhadap teks berbahasa sastra, dalam hal ini teks Al-Quran QS Yusuf (12) juz 12 dan 13. Begitu pula halnya dengan psikologi anak, psikologi komunikasi, dan seterusnya. Kata "sastra" dalam psikologi sastra, "anak" dalam psikologi anak, dan "komunikasi" dalam psikologi komunikasi merupakan objek material yang dikaji. Adapun objek formal atau sudut pandang dan pisau analisisnya adalah psikologi. Dengan demikian, hasil kajian psikologi sastra tidak berbeda dengan psikologi yang diterapkan pada non sastra ditinjau dari aspek objek formalnya, yakni membicarakan psikis manusia. Pembedanya hanya pada objek material; terdapat objek material sastra jika teks yang dikaji adalah sastra, objek material anak jika yang dikaji adalah anak dan objek material komunikasi jika yang dibahas tentang komunikasi.

Psikologi sastra membicarakan karya sastra dalam kaitannya dengan aspek-aspek kejiwaan yang terkandung dalam suatu karya sastra (Sangidu, 2005: 30). Untuk mengungkap unsur-unsur psikologi dalam karya sastra diperlukan bantuan teori-teori psikologi (Sangidu, 2005: 30). Teori psikologi yang paling banyak digunakan dalam analisis adalah teori psikoanalisa Sigmund Freud (1856-1939) yang membedakan kepribadian menjadi 3 macam, yaitu id, ego, dan Superego (Kutha, 2006: 343-344). Teori Freud dalam hal ini berfokus pada proses kreatif dan penokohan.

Endraswara (2003:97) menyatakan bahwa psikologi sastra merupakan kajian yang memandang karya sastra sebagai aktivitas kejiwaan. Ratna (dalam Albertine 2010:54) ialah berpendapat bahwa psikologi sastra memberikan perhatian pada masalah unsur kejiwaan tokohtokoh fiksional yang terkandung dalam karya. Psikologi sastra tidak bermaksud memecahkan masalah psikologis, tetapi untuk memahami aspek-aspek kejiwaan yang terkandung dalam suatu karya.

Munculnya kajian psikologi sastra tidak terlepas dari pertautan antara ilmu psikologi dan sastra. Keduanya memiliki sumber kajian yang sama yaitu manusia dan kehidupan, memiliki hubungan fungsional, yaitu sama-sama mempelajari aspek kejiwaan. Kajian psikologi sastra dapat diarahkan pada kajian tekstual yang mengkaji tokoh dalam cerita, kajian reseptif pragmatik yang mengkaji aspek psikologis pembaca, dan kajian ekspresif yang mengkaji aspek psikologis pengarang. Wellek dan Warren (1990) dan Hardjana (1985) menambahkan kajian pada penelitian hukum-hukum psikologi yang diterapkan dalam teks sastra (Endraswara, 2003: 97). Dalam kajian sastra kisah Nabi Yusuf dalam Al-Quran ini, difokuskan pada kajian tekstual, yaitu mengkaji aspek kejiwaan tokoh Nabi Yusuf dalam cerita. Melalui analisis psikologis tokoh, di samping dilakukan pemahaman terhadap tokoh, juga perlu dipahami perubahan, kontradiksi, dan penyimpangan-penyimpangan yang terjadi dalam masyarakat. 
Ada 2 jenis hubungan antara sastra dan psikoanalisis, yaitu (1) adanya kesamaan di antara hasrat-hasrat tersembunyi setiap manusia. Kehadiran karya sastra dapat menyentuh perasaan karena memberikan jalan keluar pada hasrat-hasrat rahasia tersebut. Freud melihat adanya analogi antara karya sastra dan mimpi yang juga memberikan kepuasan tak langsung pada hasrat-hasrat manusia.

(2) adanya kesamaan antara proses elaborasi karya sastra dan mimpi. Mimpi seperti tulisan yang merupakan sistem tanda yang bermakna. Mimpi seperti karya seni, utamanya seni lukis dan seni pahat.Pemahaman eksistensinya diperlukan interpretasi. Jika karya sastra terdiri atas bahasa yang bersifat linier maka mimpi terdiri atas tanda-tanda figuratif yang tumpang tindih dan tidak linier. Mimpi sebagaimana seni lukis. Antara mimpi dan karya sastra sama-sama menghadirkan simbul yang mengandung makna konotatif di samping makna denotatif.

Karya yang bermutu menurut pendekatan psikologis adalah karya yang menyajikan simbulsimbul, wawasan, perlambangan yang bersifat universal; karya yang mampu menggambarkan kekalutan dan kekacauan batin manusia karena hakekat kehidupan itu adalah perjuangan menghadapi permasalahan hidup. Perilaku yang tampak dalam kehidupan sehari-hari seseorang belum sepenuhnya menggambarkan diri mereka. Apa yang diperlihatkan belum tentu sama dengan apa yang sesungguhnya terjadi di dalam dirinya karena seringkali manusia menutup nutupi sebagian dari apa yang terjadi padanya (Semi, 1990: 78). Gejolak batin manusia kadang termanifestasikan dalam tindakan riil, tetapi sering pula tidak tampak gejalanya dari luar. Karena itu, kajian perwatakan tokoh, kejiwaan tokoh menjadi penting untuk di kupas.

Dalam analisis psikologi sastra, teks ditempatkan sebagai objek penelitian, dalam hal ini kisah Nabi Yusuf. Setelah itu, ditentukan teori psikologi tertentu yang dianggap relevan, dalam hal ini teori psikoanalisa, memahami teori tersebut, kemudian dilanjutkan analisis terhadap teks (Kutha, 2006: 346). Teori Freud dimanfaatkan dalam mengkaji kisah Nabi Yusuf untuk mengungkapkan berbagai gejala psikologis di balik gejala bahasa kisah Nabi Yusuf dalam AlQuran.

Aspek-aspek kemanusiaan Nabi Yusuf menjadi objek utama psikologi. Kajian psikoanalisis lebih menekankan pada kajian aspek intrinsik dibanding dengan aspek ekstrinsik karya sastra. Aspek intrinsik terkait tema, tokoh dan penokohan, alur, dan unsur-unsur kejiwaan tokoh dalam karya (Sangidu, 2005: 30). Kajian ini tidak hanya berkutat pada perilaku tokoh saja, tetapi juga dikaitkan dengan hubungannya dengan realitas, sebagai fenomena individual ataukah sosial (Endraswara, 2003:98). Adapun kajian ekstrinsik terkait dengan misi dan tujuan hadirnya kisah ini dalam Al-Quran.

Menurut Milner (1992: xiii), teori Freud memiliki implikasi yang luas dalam memahami teks. Hubungan psikologi dengan sastra sebagaimana pasien dengan dokter. Sastra menampilkan ketaksadaran bahasa. Kemampuan peneliti dalam mengungkap ketaksadaran bahasa dalam karya sastra, seperti pengulangan yang terkait dengan bahasa tokoh, gaya bahasa, latar dan lain-lain merupakan unsur penting dalam analisis ini.

Dalam analisis psikologi, penting pula dikemukakan analisis pengaruh karya sastra terhadap pembaca. Utamanya pengaruh yang menimbulkan kesan yang mendalam dalam jiwa yang berdampak pada aspek didaktis bagi manusia. Seni adalah sumber dari rasa keindahan. Salah satu bentuk seni sastra adalah cerita yang umumnya memiliki unsur edukatif. Cerita tidak hanya disukai oleh anak-anak, tetapi juga orang dewasa (Majid, 2002:8). Cerita dijadikan salah satu media oleh Allah dalam menyampaikan wahyu-Nya agar manusia dapat mengambil pelajaran dari cerita tersebut .

\section{Kisah Nabi Yusuf dalam Perspektif Psikologi Sastra}

Dalam al-Quran, kisah Nabi Yusuf secara keseluruhan tertera dalam surat Yusuf (QS.12), diturunkan di Mekah, terdiri atas 111 ayat, dan terletak setelah surat Hud (11) dan sebelum surat Ar-Raad (13). Menurut Quraish Shihab, turunnya surat ini bertujuan untuk menguatkan hati nabi 


\section{Arabi : Journal of Arabic Studies}

yang saat itu sedang dirundung kesedihan akibat wafatnya istri dan pamannya; Siti Khadijah dan Abu Thalib. Adapun menurut al Biqâ’i, tujuan utama turunnya kisah ini adalah untuk membuktikan bahwa kitab suci Al-Quran benar-benar merupakan penjelasan menyangkut segala sesuatu yang mengantar pada petunjuk (tilka âyâtul kitâbil Mubîn), berdasar pengetahuan dan kekuasaan Allah swt secara menyeluruh, baik yang nyata maupun yang gaib. Kisah Nabi Yusuf terdiri atas 10 episode, yaitu mimpi Nabi Yusuf, Nabi Yusuf disingkirkan saudaranya, Nabi Yusuf dijual kepada orang Mesir, rayuan istri orang kepada Nabi Yusuf, jamuan makan, dalam penjara, mimpi raja dan kebebasan Nabi Yusuf, Nabi Yusuf menjadi pejabat pemerintah, pertemuan dengan keluarga, dan i'tibar dari kisah Nabi Yusuf. Masing-masing episode tersebut, dijabarkan sebagai berikut.

Pada episode pertama, Nabi Yusuf bermimpi melihat 11 bintang, serta matahari dan bulan bersujud kepadanya.

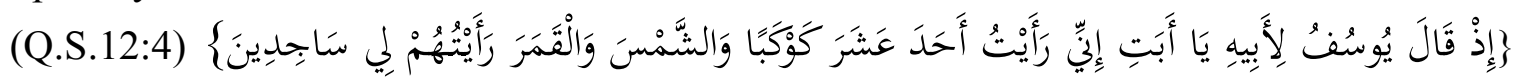

Nabi Yusuf memanggil ayahnya tanpa sebutan nama Ya'kub, tetapi langsung "yâ abati/ "بت" (wahai ayahku). Nabi Yusuf juga tidak memanggil ayahnya dengan menggunakan kata "yâ " أبي (wahai ayahku). Pada ayat 100 juga diulang kembali panggilan "yâ abatî" oleh yusuf:

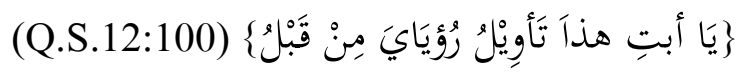

Di dalam Al-Quran, terdapat 8 ayat yang menyertakan kata "yâ abati" yang kesemuanya ta dilekatkan pada kata " $a b$ " (ayah). 4 ayat dilafalkan oleh Nabi Ibrahim (baca Q.S. Maryam: 42, 43,44,dan 45); 2 ayat oleh Nabi Yusuf (baca Q.S.Yusuf: 4 dan 100), 1 ayat oleh nabi Ismail (baca Q.S. Ash-Shaffat: 102), dan 1 ayat oleh anak Nabi Syuaib (baca Q.S. Al-Qashash: 26).

Berdasarkan kajian terhadap berbagai ilmu tafsir, penulis menemukan rahasia dibalik panggilan khusus ini. Kata "yâ abati" merupakan pengganti dari kata " yâ abiy". Kata ganti orang pertama (Ya mutakallim) pada kata "abiy" diganti dengan ta pada kata "abati". Sebagaimana dikatakan Sibawaih, ta itu pengganti ya idhafah sehingga tidak perlu lagi ditambah ya idhafah setelah ta karena keduanya tidak boleh berkumpul bersama-sama. Dijelaskan pula bahwa "yâ abati " hanya dipakai untuk kata tentu (marifah) dan tidak berlaku untuk kata tak tentu (nakirah). Ta sebagai pengganti yạ mutakallim yang hilang, "yâ abiy" menjadi "yâ abati"

Ditinjau dari aspek retorika dan makna tambahan yang dimunculkan, penggunaan kata panggilan "yâ abati" berbeda dengan "yâ abiy". Konteks ayat ini mendorong penggunaan panggilan "yâ abati" karena adanya perasaan, emosi, cinta, dan kasih sayang dari seorang anak kepada ayahnya yang amat sangat dan itu tidak didapatkan pada kata "yâ abiy" yang hanya merupakan panggilan yang sudah biasa dan dipakai sehari-hari. Seorang anak yang memanggil ayahnya dengan penuh kasih sayang dan cinta kasih ketika bermimpi indah, ia ingin berbagi kebahagiaan dengan ayahnya. Panggilan "yâ abati" adalah panggilan kasih sayang dan cinta dan menunjukkan hubungan cinta kasih yang sangat kuat antara seorang ayah dengan anaknya. Panggilan yang memuat makna sabar dan keinginan agar terkabulkannya permintaan. Secara psikologis, hal ini menunjukkan kedekatan Yusuf kepada ayahnya. Makna ini tidak ditemukan pada kata "yâ abiy".

Tidak hanya cinta seorang anak kepada ayah, tetapi dalam kisah ini juga ditampakkan kuatnya cinta ayah kepada anak. Kedekatan dan kasih sayang seorang ayah kepada Yusuf juga ditunjukkan sang ayah dengan panggilan "wahai anakku" "Yâ bunayya" sebagai bentuk tashghîr dari frasa wahai anakku " yâ ibnî".

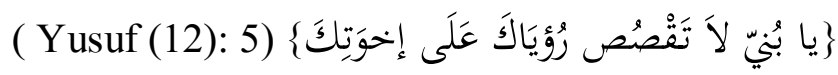

Tashghir dibentuk dengan memberi syakal dhummah di awal kata, kemudian memberi syakal fathah pada huruf kedua dan menambahkan ya sakinah setelahnya. Huruf ya' tersebut dinamakan ya tashghir. Tujuannya adalah mengecilkan, memandang rendah, mengurangi jumlah, 
menunjukkan kedekatan waktu, tempat, dan untuk mengagungkan (Zulfiqar bin Thahir, Saidna dan Syarifah L.A., 2006) .

Panggilan "Yâ bunayya"menunjukkan rasa kasih sayang dan cinta seorang ayah kepada anak. Di dalam Al-Quran, panggilan dengan menggunakan sebutan tashghir "Yâ bunayya” itu terdapat di 5 tempat, yaitu pertama dilafalkan oleh Nabi Nuh (baca QS. Hud: 42), oleh Nabi Yakub (baca QS. Yusuf :5), oleh Luqman (baca QS. Luqman: 13 dan 16), dan oleh Nabi Ibrahim (baca QS. Ash-Shaffat: 102).

Dalam ilmu retorika bahasa Arab, seruan “ $y a ̂$ ” digunakan untuk memanggil orang yang jauh atau menunjukkan ketinggian dan kedudukan orang yang dipanggil. Jika seruan itu kemudian digunakan untuk memanggil orang yang dekat, maka itu menunjukkan adanya tujuan sastra, yaitu menambah intensitas rasa bagi yang mendengarnya dan menunjukkan betapa dekatnya hubungan penutur dan mitra tuturnya, dalam hal ini ayah dan anak.

Dalam kaitannya dengan mimpi Nabi Yusuf, pada ayat 4 surat Yusuf, frasa "raaitü" disebut sebanyak 2 kali dan di awali ayat ini dengan penegas inna (sesungguhnya). Secara psikologis, hal ini menunjukkan kuatnya pengaruh mimpi itu dalam jiwa Nabi Yusuf. Adapun dalam tafsir aththabari (14444-14447), dikatakan bahwa ahada asyara itu adalah saudara-saudaranya dan asysyams wal qamar adalah orang tuanya.

Freud memandang mimpi sebagai jalan utama menuju ke alam tak sadar karena dia melihat isi mimpi ditentukan oleh keinginan-keinginan waktu sadar yang direpres. Karenanya, mimpi juga bisa ditafsirkan sebagai pemuasan simbolis dari keinginan-keinginan. Dengan teknik penafsiran mimpi yang menyertakan analisis atas makna-makna yang samar dari simbul-simbul mimpi, akan ditemukan gejala atau konflik motivasional yang dialaminya (Koswara, 1991: 65-66).

Mimpi Nabi Yusuf melihat sebelas bintang dan bulan yang bersujud kepadanya tidak terlepas dari kondisi Nabi Yusuf pada saat itu di antara saudara-saudaranya. Secara psikologis dan naluri, sebagai anak terkecil, ia mengharapkan kasih sayang dari para saudaranya. Namun, keinginan itu tidak terwujud akibat rasa cemburu saudara Nabi Yusuf kepadanya akibat rasa cinta seorang ayah yang lebih kepada Nabi Yusuf dibanding kepada mereka. Posisi Nabi Yusuf yang lemah pada saat itu mengakibatkan ia punya obsesi dan cita-cita yang ditekan di alam bawah sadar. Berbagai obsesi, keinginan, dan cita-cita itu kemudian terbawa ke alam bawah sadarnya hingga akhirnya ia bermimpi melihat 11 bintang yang bersujud kepadanya.

Namun demikian, mimpi tersebut tidak dapat dipisahkan dari rangkaian teks Al-Quran sebagai petunjuk Allah dan Nabi Yusuf sebagai manusia pilihan. Sebagai calon Nabi, ia bermimpi tentang masa depan (sistem ingatan jangka panjang) yang akan dialaminya. Sebagai implikasi dari mimpi sebagai petunjuk ini adalah sikap tahan banting yang dimiliki Nabi Yusuf dalam menghadapi berbagai cobaan, mulai cobaan ditinggal wafat oleh sang ibu, dikucilkan oleh saudarasaudaranya yang merasa cemburu, dimasukkan ke dalam sumur, dicintai oleh istri al-Aziz, hingga sampai masuk penjara.

Mimpi yang berada di bawah sadar manusia memiliki dampak kejiwaan bagi yang mengalaminya. Dampak mimpi yang baik akan membahagiakan dan dampak mimpi negatif akan menyedihkan. Berdasarkan teori psikologi Freud, mimpi itu bagai lukisan atau bagai seni pahat yang memiliki makna simbolik sebagaimana bahasa. Nabi Ya'kub telah menjelaskan makna simbolik itu. Secara psikologis, ketika tokoh Nabi Yusuf bermimpi dan menceritakan mimpi itu kepada Nabi Ya'kub, hal itu disebabkan karena kebahagiaan akibat mimpi itu juga ingin dibagi bersama orang yang paling dekat di hatinya.

Menurut Freud, hadirnya mimpi dapat menyentuh perasaan karena memberikan jalan keluar pada hasrat-hasrat rahasia yang tersembunyi dalam diri manusia. Freud melihat adanya analogi antara karya sastra dan mimpi yang juga memberikan kepuasan tak langsung pada hasrat-hasrat manusia. Kisah mimpi tokoh Nabi Yusuf yang menyenangkan diceritakan kepada ayahnya yang disayanginya itu turut merasakan kebahagiaan itu. 


\section{Arabi : Journal of Arabic Studies}

Sebagaimana teori Freud, ada kesamaan antara proses elaborasi karya sastra dan mimpi. Keduanya merupakan sistem tanda yang bermakna. Pemahaman eksistensinya diperlukan interpretasi. Keduanya menghadirkan simbul yang mengandung makna konotatif /makna sastra (meaning of meaning/significant) di samping makna denotatif. Makna denotatif mimpi melihat sebelas bintang, matahari dan rembulan yang bersujud itu sebagaimana yang tersurat dalam bahasa. Adapun makna konotatifnya adalah tunduknya 11 saudara kepadanya dan datangnya ibu dan Bapaknya bersama mereka ke Mesir pada saat Nabi Yusuf memegang tampuk kepemimpinan.

Nabi Ya'kub menasehati anaknya agar tidak menceritakan mimpi itu kepada saudaranya agar tidak memperkeruh hubungan persaudaraan mereka. Hal ini menunjukkan bahwa mimpi itu adalah mimpi yang bagus dan membahagiakan keduanya sehingga tidak perlu diketahui saudaranya yang suka cemburu pada kedekatan Ya'kub dan anaknya. Nabi Yusuf menjadi bertambah berkesan dan bahagia dengan mimpi itu ketika sang ayah menjelaskan makna mimpi itu, bahwa (1) ia sebagai makhluk pilihan Allah yang (2) akan diajarkan kepadanya ta'wilul ahââits, yaitu penafsiran tentang mimpi (QS.12: 6, 21), dan (3) Allah akan memberikan kebahagiaan hidup dunia dan di akherat, yaitu dengan diangkat sebagai nabi sebagaimana leluhur Nabi Ibrahim dan Nabi Ishaq.

Pada episode kedua, Nabi Yusuf disingkirkan oleh para saudaranya. Kepribadian id mereka mendominasi ketika sepakat untuk memasukkan Nabi Yusuf ke dalam sumur. Ego mereka muncul ketika melaksanakan rencana itu. Adapun kepribadian superego muncul ketika mereka berkeinginan untuk menjadi orang yang saleh setelah kejadian itu. Mereka sepakat untuk tidak membunuh Nabi Yusuf, tetapi hanya menyingkirkannya. Hal ini berarti mereka masih dikendalikan oleh superego mereka. Sumur yang ditempati untuk membuang Nabi Yusuf adalah sumur yang tidak terlalu banyak airnya, tidak terlalu dalam, bahkan mereka memperkirakan sumur itu sering dilewati oleh para musafir untuk beristirahat dan mengambil air di sumur itu. Mereka berharap Nabi Yusuf akan dibawa oleh musafir dan jauh dari kehidupan mereka dengan maksud agar Nabi Ya'kub akan mencintai mereka sebagaimana cintanya kepada Nabi Yusuf.

Umumnya, seorang anak kecil yang diletakkan dalam sumur dalam keadaan tak berbaju lalu ditinggalkan saudaranya, pastilah ada rasa takut, cemas, khawatir yang dikejawantahkan melalui tangisan dan jeritan. Tetapi Nabi Yusuf tidak demikian. Ia terhibur dengan makna mimpi yang diceritakan sang ayah. Apalagi, ia mendapat wahyu ketika berada di sumur itu bahwa ia tidak perlu khawatir dan pasti Allah akan menyelamatkannya. Suatu ketika, ia akan menceritakan perbuatan ini kepada mereka (QS.12: 15). Jiwa yang pasrah dan tawakkal serta keimanan yang penuh kepada Dzat tertinggi Yang Maha menolong mengakibatkan jiwa Nabi Yusuf menjadi tenang.

Berdasarkan teori psikologi perkembangan, dinyatakan bahwa anak usia 8 -10 tahun berada dalam tahapan katarsis emosional. Ia mampu memanfaatkan emosi, mengontrol emosi, mengendalikan emosi dalam rangka pencarian identitas diri. Pencarian jati diri itu dimulai dengan sikap menyembunyikan emosi, meninggalkan emosi, dan penyesuaian emosi dengan situasi. Emosi pada masa ini sudah mencapai taraf keseimbangan (Baraja, 2008: 144-146). Pada usia 10-13 tahun anak berada dalam tahapan motivasional, yakni seorang anak memiliki harapan untuk dapat mencapai sesuatu yang diinginkan. Pada masa ini anak akan melanjutkan pencarian jati diri melalui penggunaan kemampuan kognitif, afektif, dan kemampuan fisik (Baraja, 2008: 148-151). Jika Nabi Yusuf pada waktu dimasukkan ke dalam sumur berada dalam usia sebagaimana tersebut, berarti emosi Nabi Yusuf ketika menghadapi perilaku para saudaranya secara psikologis sudah bisa dikendalikan dan tertata.

Sikap membohongi orang tua dengan sedih dan menangis yang dilakukan oleh para saudara Nabi Yusuf menunjukkan bahwa kebohongannya tidak ingin diketahui sang ayah. Karena itu, mereka berusaha menutupi dengan membawa bukti baju Nabi Yusuf yang berlumuran darah. Jiwa Nabi Ya'kub yang berduka itu kemudian terobati dengan sikap bersabar dan berserah diri kepada Allah (QS.12: 18). 


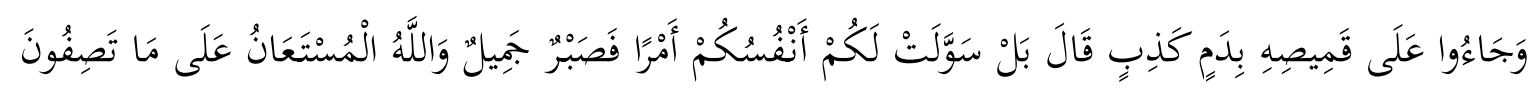

(QS.12:15)

Tujuan kesabaran itu adalah untuk menjaga keseimbangan emosi agar hidup tetap stabil. Sabar bukan berarti tidak bertindak, tetapi ia ibarat benteng pada saat menghadapi musuh yang kuat. Dari dalam benteng, seseorang mempersiapkan diri kemudian terjun menghalau musuh sekuat kemampuan (Qurays Shihab, 2002: 400).

Pada episode ketiga, Nabi Yusuf dijual kepada orang Mesir. Para musafir merasa senang ketika menemukan Nabi Yusuf . Kesenangan itu akibat prediksi keuntungan ekonomis yang akan mereka peroleh. Kesenangan itu juga ditunjukkan oleh frasa Yâ busyrâ yang digunakan dalam QS.12: 19.

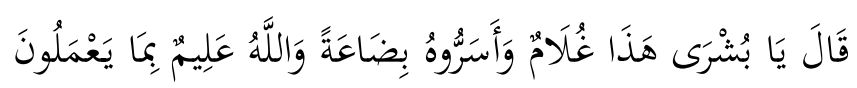

Menurut Quraish Syihab, kata ghulâm menunjukkan usia Nabi Yusuf saat itu antara 10-20 tahun. Adapun Sayyid Quthub memperkirakan usia Nabi Yusuf saat itu tidak kurang dari 14 tahun. Sesudah itu, seseorang dinamai fatâ kemudian rajul.

Orang yang membeli Nabi Yusuf pun merasa senang. Hal ini diketahui dari sikapnya terhadap Nabi Yusuf, yaitu (1) menjadikannya sebagai anak, (2) diberi tempat dan pelayanan yang baik. Secara psikologis, seseorang yang sudah bersuami istri pastilah menginginkan keturunan. Ketika keinginan itu belum tercapai, terdapat rasa berharap dan terus berharap. Keinginan dan kesungguhan mereka mengambil Nabi Yusuf sebagai anak juga dibuktikan dengan penambahan ta' pada kata ittakhadza (QS.12:21). Ketika pembeli Nabi Yusuf tidak memiliki anak dan kemudian mendapatkan anak dengan cara yang mudah, maka jiwanya menjadi lebih tenang dan bahagia.

Nabi Yusuf sebagai perantara rasa bahagia ini menjadikan keluarga ini memperlakukan Nabi Yusuf secara baik. Keluarga yang dimaksud adalah keluarga seorang menteri yang memiliki istri bernama Zulaikha yang terkenal di Indonesia dengan sebutan Zulaikha. Sayyid Quthub menyatakan bahwa umur Nabi Yusuf saat itu 25 tahun dan usia Zalikha 40 tahun. Anak laki-laki pada usia 25 tahun sudah tampak kematangan fisik dan psikisnya. Secara psikologis, Zulaikha sebagai seorang istri yang telah berusia 40 tahun telah memiliki kematangan emosi, kemampuan, dan keberanian untuk menggoda lawan jenisnya.

Pada episode keempat, terjadi rayuan seorang istri kepada Nabi Yusuf. Istri orang Mesir yang mengetahui perkembangan Nabi Yusuf dari hari ke hari, melihat keindahan parasnya, kejernihan matanya, kegagahan dan kehalusan budinya menyebabkan ia jatuh hati padanya. Secara psikologis, seseorang yang dilanda cinta, pada mulanya ia akan memendam rasa. Artinya tidak langsung mengatakannya, hal itu karena rasa yang bercampur baur. Ketika gejolak jiwa pecinta itu sudah memuncak, maka ia akan berusaha untuk menundukkan sasarannya dengan menyatakan cintanya, baik secara eksplisit maupun implisit. Dalam ayat ini, dikatakan istri itu menggodanya untuk menundukkannya. Ini berarti bahwa upaya menggoda itu tidak hanya sekali, tetapi beberapa kali supaya tunduk.

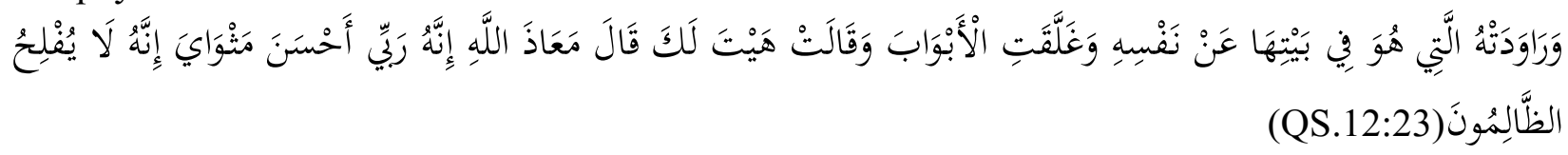

Kata râwadathu berasal dari kata râwada yang asalnya adalah râda. Dalam tafsir AlMishbah, kata ini mengandung arti meminta sesuatu dengan lemah lembut agar apa yang diharapkan-dan enggan diberi oleh orang yang dimintai- dapat diperoleh. Bentuk kata yang digunakan ini mengandung makna upaya berulang-ulang. Pengulangan itu terjadi karena langkah pertama ditolak, sehingga diulangi lagi dan begitu seterusnya. Ini menunjukkan bahwa perempuan itu benar-benar menyukai Yusuf. Hal ini juga dipertegas pada ayat berikutnya (QS.12:24) yang

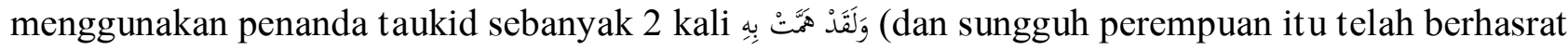
kepada Yusuf) yang ditujukan pada hasrat perempuan kepada Nabi Yusuf, sedangkan untuk Nabi 


\section{Arabi : Journal of Arabic Studies}

Yusuf tanpa diberi penanda taukid وَهَمَّ (dan (dan Yusuf pun berkehendak kepadanya). Artinya, Nabi Yusuf pun sebagai manusia yang punya id, ego, dan superego juga memiliki sikap senang kepada lawan jenis. Hanya saja, rasa itu tidak seberapa dibanding dengan Zulaikha.

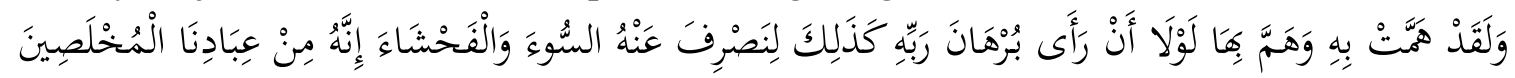

(QS.12:24)

Sikap seorang istri itu telah didominasi oleh kepribadian id dan egonya. Sementara Nabi Yusuf dengan berpegang pada wahyu, telah dikendalikan sikapnya oleh superegonya. Kepribadian id yang mendominasi wanita itu juga ditunjukkan oleh sikapnya yang mengoyak baju Nabi Yusuf dari belakang. Hasrat birahi yang muncul dari dalam diri wanita itu tidak terbendung akibat gejolak cinta yang sudah lama terpendam.

Berdasarkan sikap yang ditampakkan oleh Zulaikha dan Nabi Yusuf, diketahui bahwa secara psikologis, Zulaikha mengalami frustasi karena keinginannya yang berkali-kali ditolak hingga ia memaksa Nabi Yusuf. Berdasar teori psikologi, seseorang akan mengalami frustasi karena keinginannya tidak terpenuhi. Tidak terpenuhinya harapan dan keinginan tersebut bisa disebabkan faktor fisik maupun psikis. Frustasi ada tiga jenis, yaitu: (a) sosial, (b) individual, dan (c) komplit (Floyd and G. Philip, 1971: 461). Frustasi yang dialami Zulaikha termasuk frustasi individual sekaligus sosial.

Lapis ego yang mengalami frustasi akan merasa sakit, lalu bereaksi secara tidak sadar untuk mengurangi tekanan batin yang menimbulkan rasa sakit atau stress. Reaksi itu disebut reaksi mekanistik (defense machanism) . Reaksi itu dilakukan oleh lapis ego dalam rangka mempertahankan harga diri. Reaksi mekanistik dapat dibagi tiga, yaitu (a) reaksi agresif, berupa menyerang atau menyakiti, (b) reaksi menghindar atau menarik diri, dan (c) reaksi mengganti atau kompromi. Reaksi agresif tadi dapat berwujud mengkambinghitamkan, marah tanpa pandang bulu, atau menyalahkan diri sendiri (Floyd and G. Philip, 1971: 403-404). Jadi orang yang frustasi akan mengalihkan kemarahannya pada objek lain sebagai sasaran pengganti.

Adapun reaksi menghindar dari situasi yang menyebabkan frustasi,wujud menghindar bisa berupa tindakan fisik atau psikis. Adapun reaksi mengganti atau kompromi adalah menurunkan derajat keinginan semula agar hasrat tetap terealisasi meskipun kurang maksimal (Floyd and G. Philip, 1971: 471).

Kepuasan langsung atas kebutuhan atau keinginan tertentu sering tidak bisa terwujud sebab sasaran yang hendak digapai secara fisik tidak terjangkau atau tindakan yang diupayakan untuk menggapai sasaran hanya membangkitkan rasa tidak menyenangkan. Dalam kondisi seperti itu, seseorang bisa mengalihkan sasaran untuk memperoleh kepuasan meskipun tidak akan memberi kepuasan seperti tujuan semula. Penggantian kepuasan inilah yang disebut konsep sublimasi.

Adapun reaksi mekanistik yang dilakukan oleh Zulaikha adalah reaksi agresif, yaitu menyerang Nabi Yusuf dengan membuatnya di penjara dan mengundang para perempuan di lingkungannya yang telah mencibir perbuatannya dengan mengundang mereka pada jamuan makan malam. Hal itu dilakukan dalam rangka rasionalisasi.

Rasionalisasi adalah proses merekayasa alasan agar logis atas situasi tertentu, karena jika dibiarkan akan mengakibatkan hilangnya harga diri di hadapan masyarakat. Seseorang yang mencari pembenaran sebenarnya ia takut celaan orang lain atas dirinya. Rasionalisasi adalah mekanisme yang dilakukan diri dalam upaya mengantisipasi kritikan atau mempertahankan diri terhadap tekanan atas kegagalan. Rasionalisasi adalah bentuk mencari-cari alasan agar tidak turun harga dirinya di hadapan orang lain (Siswantoro, 2005:177). Secara psikis istri Al Aziz ingin membela diri ketika posisinya di hadapan keluarga dan lingkungan sudah tercemar akibat perilaku yang tidak sepantasnya.

Pada episode kelima, terdapat jamuan makan (QS.12:30). Para undangan yang terdiri atas para wanita itu menggunjing sikap istri Al-Aziz yang menggoda Yusuf. Maka ketika ia mendengar gunjingan itu, istri Al-Aziz meminta para wanita itu untuk memegang pisau dan buah. 
Terperangahlah mereka ketika melihat Nabi Yusuf yang sangat tampan sampai terpotonglah jari tangan mereka.

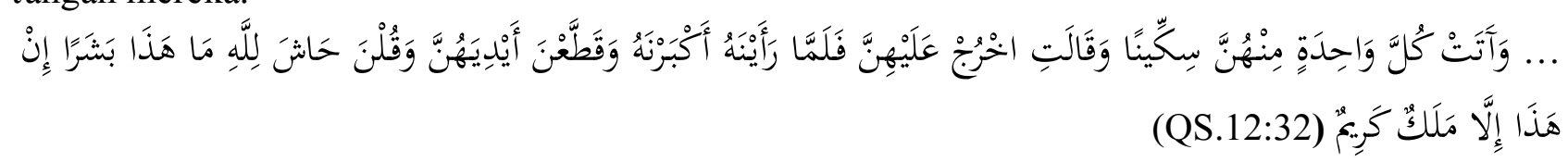

Huruf sin dan ta' pada kata ista'shama pada ayat 32 dari surat ini menunjukkan makna kesungguhan Nabi Yusuf dalam menolak istri Al-Aziz.

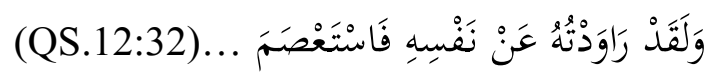

Selanjutnya kata layusjananna/ ليسجنن menggunakan nun taukid ats tsaqîlah menurut al biqai menggambarkan gejolak jiwa pengucapnya, yaitu istri Al-Aziz yang kecewa dengan sikap Nabi Yusuf yang menolaknya. Akhirnya, Nabi Yusuf pun di penjara atas kemauan sendiri (QS.12: 34).

Pada episode keenam, diceritakan bahwa Nabi Yusuf berada di penjara bersama dua orang pemuda. Di penjara inilah Nabi Yusuf menjadi pena'wil mimpi 2 orang pemuda tadi. Pena'wil pertama menggembirakan bagi yang menerima mimpi itu, yaitu ia akan kembali ke rumah tuannya, melakukan pekerjaan semula dan takwil kedua merupakan takwil yang mencekam jiwa yang bermimpi itu sehingga ia berkata bahwa mimpinya tadi hanyalah bohong belaka. Takwilnya adalah ia akan disalib dan digantung, lalu burung makan sebagian kepalanya.

Pada episode ketujuh, Nabi Yusuf mendapat kesempatan untuk menakwilkan mimpi sang raja. Karena ta'wilnya benar, maka ia dibebaskan. Adapun pada episode kedelapan, Nabi Yusuf menjadi pejabat pemerintah (QS.12: 54-55). Ia minta jabatan sebagai bendaharawan Negara. Permintaan ini didorong oleh rasa percaya diri Nabi Yusuf dan sikapnya yang jujur. Ia meminta jabatan sesuai dengan spesifikasi yang dimilikinya, yaitu chafídzun 'alîm.

Dalam teori psikologi, kekuasaan merupakan salah satu kebutuhan dasar manusia. Kebutuhan (needs) adalah keadaan yang menimbulkan motivasi. Maslow membagi kebutuhan menjadi lima tingkat, yaitu (1) kebutuhan biologis, (2) kebutuhan rasa aman, terhindar dari kecemasan dan ketakutan, (3) kebutuhan sosial (mencintai dan dicintai), (4) kebutuhan-kebutuhan harga diri, dan (5) kebutuhan aktualisasi diri. Adapun McCleland berpendapat bahwa setiap orang memiliki tiga jenis kebutuhan dasar, yaitu (1) kebutuhan akan kekuasaan, yaitu keinginan untuk mempengaruhi orang lain, (2) kebutuhan untuk berafiliasi, yaitu kebutuhan untuk memiliki teman, menjalin persahabatan, dan (3) kebutuhan berprestasi, yaitu kebutuhan untuk berhasil dalam tugastugas, nilai akademik yang baik, memperoleh penghargaan dan lain-lain (Nur Salim, 2007: 118119; Kuswara, 1991 : 118-127).

Pada episode kesembilan, Nabi Yusuf dipertemukan dengan keluarganya (Qs.12:58-61). Para saudara Nabi Yusuf yang datang padanya untuk mengambil jatah bahan makanan yang dibagikan kepada penduduk Mesir dan sekitarnya. Rasa rindu Yusuf kepada Benyamin dan ayahnya yang telah terpendam lama, mendapatkan kesempatan untuk bertemu. Pertemuan dengan saudara ini dalam teori kebutuhan termasuk kebutuhan sosial.

Adapun episode kesepuluh merupakan i'tibar dari kisah Nabi Yusuf (QS.12: 102-111), di antaranya menjelaskan prinsip-prinsip segala yang dibutuhkan manusia menyangkut kemaslahatan hidup di dunia dan akherat.

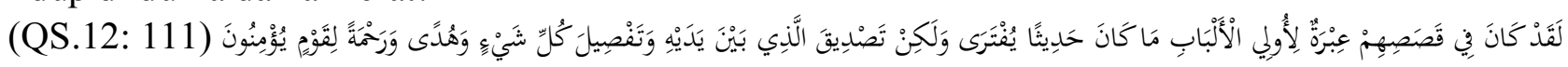

Kisah Nabi Yusuf memberikan pelajaran bagaimana seseorang yang harus tetap teguh pada keimanan dan prinsip-prinsip Islam meskipun menghadapi berbagai ujian dan cobaan hidup yang silih berganti. Kesabaran dan tidak putus asa serta bertawakkal akan membuahkan kesuksesan. Kejujuran akan membawa manusia pada derajat yang tinggi. Rasa takut kepada Allah dan selalu merasa dalam pengawasan Allah telah membuat manusia terhindar dari perbuatan keji. Allah akan selalu menolong hambanya yang selalu berdoa, baik di kala sempit maupun di kala lapang. 


\section{Arabi : Journal of Arabic Studies}

Melalui kisah ini, terdapat pelajaran bagi umat manusia untuk selalu menuntut ilmu dan berbuat baik dan menebarkan kebaikan serta menjadi pemaaf bagi para pendengki.

\section{Simpulan}

Kajian interdisipliner mampu mengungkap lebih lengkap sisi-sisi teks. Ia mengungkap lebih jauh dari sekedar aspek struktur, tetapi mengkaitkan struktur dengan aspek ekstrinsik teks. Kisah Nabi Yusuf dalam surat ini merupakan kisah yang terbaik (ahsanul Qashash) dari aspek gaya, kandungan, dan tujuannya. Nabi Yusuf mengampuni saudara-saudaranya dan bersikap sabar atas tindakan mereka. Ia menjaga kehormatannya dan rela berkorban demi menegakkan kebenaran. Akibat sikapnya itu dan disertai dengan ketinggian ilmu, ia mendapatkan kedudukan yang mulia di sisi Allah dan masyarakatnya.

Dalam kaitannya dengan Islam, superego yang sekuler dalam teori Freud hendaknya diarahkan pada nilai-nilai Islam yang berpihak kepada Allah. Nilai yang dimaksud adalah perilaku taqwa, takut kepada Allah dengan menjalankan perintah dan menjauhi larangannya. Prinsip tauhid harus dipegang sehingga ketika hasrat berbuat buruk muncul dalam diri seorang muslim, maka prinsip tauhid yang dipegang tegung akan mampu menjadi bentengnya. Yang haq pastilah menang dan yang bathil pastilah kalah (إن الباطل كان زهوقا). []

\section{Daftar Rujukan}

Abdul Chaer. 2009. Sosiolinguistik. Jakarta. Rineka Cipta.

Abdul Majid, Abdul Aziz. 2002. Mendidik dengan Cerita. Bandung: Rosdakarya.

Akrom, Muhammad. 2014. "Analisis Ketampanan Nabi Yusuf dalam Perspektif Semiotika AlQur'an”, Arabiyat : Jurnal Pendidikan Bahasa Arab dan Kebahasaaraban Vol 1 No 2.

American Heritage. 2000. Dictionary of the English language, Fourth Edition, Dream.

Atar Semi, M. 1990. Metode Penelitian Sastra. Bandung: Angkasa.

Bertens, K. 1984. Sigmund Freud: Memperkenalkan Psikoanalisa. Jakarta: PT Gramedia.

Coutts, R . 2008. "Dreams as modifiers and tests of mental schemas: an emotional selection hypothesis" dalam psychological report, 102,561-574

Departemen Agama RI. 2006. Al-Quran dan Terjemahnya.

Endraswara, Suwardi. 2003. Metodologi Penelitian Sastra. Yogyakarta: Pustaka Widyatama.

Fananie, Zainuddin. 2000. Telaah Sastra. Surakarta: Muhammadiyah University Press.

Freud, S. 1940. An outline of psychoanalysis. London: hogarth press

Gatot. 2014. "Kajian Psikologi Sigmund Freud pada Tokoh Aku dalam Cerpen Bola Lampu Karya Asrul Sani", dalam Prasasti Bahasa dan Sastra Indonesia, diakses 12 Mei 2016

Ghazali. 2006. "Teori Mimpi dalam Perspektif Psikologi Sufi Ibn Arabi dan Psikoanalisis Sigmund Freud" dalam Majalah online Kajian Islam dan Psikologi alumni PPS UI . Psi.islami. bblogspot.com. 2006.

Hobson, J.A. and McCarly, R.W. 1977. "The Brain as a dream-state generator: an activationsynthesis hypothesis of the dream process" dalam American Journal of Psychiatry, 134, $1335-1348$

Kuswara, E. 1991. Teori-teori kepribadian . Bandung: Eresco.

Milner, Max. 1992. Freud dan Interpretasi Sastra. Jakarta: Intermassa.

Neil J. Salkind. Tt. Teori-teori Perkembangan Manusia. Penerbit Nusamedia

Vol. 1 No. 2 | 88-89

Copyright ( 2016 | ARABI | p-ISSN 2548-6616 | e-ISSN 2548-6624 
Nursalim, Muchammad, dkk. 2007. Psikologi Pendidikan. Surabaya: Unesa University Press.

Prentice, A.E. 1990. "Introduction" dalam Information Science-The Interdiciplinary Contex (ed.J.M. Pemberton dan A.E.Prentice. New York: Neal -Schuman Publishers.

Ratna, Nyoman Kutha. 2006. Teori Metode, dan teknik Penelitian Sastra. Yogyakarta: Pustaka Pelajar.

Rofiq Hasan al-Halimiy. 2011. "Ya abati wa chaqiqatu charfu at tă", dalam Majallah al-wă'yu alIslamiy, http://m.facebook.com. Diakses 12 Mei 2016

Sangidu, 2005. Penelitian Sastra: Pendekatan, Teori, metode, teknik dan kiat. Yogyakarta: Seksi Penerbitan Sastra Asia Barat UGM.

Saryono, Djoko. 2015. Menuju Era Multidisipliner dalam kajian Bahasa dan Sastra Indonesia, dalam http://library.um.ac.id. Diakses 26 Oktober 2015.

Segers, Rien T. 2000. Evaluasi Teks Sastra. Yogyakarta: Adicita.

Shihab, M. Quraish. 2002. Tafsir Al-Mishbah: Pesan, kesan dan keserasian Al-Quran. Jakarta: Lentera Hati.

Sirin, Muhammad Ibnu. 2004. Tafsir Mimpi menurut al-Quran dan as-Sunnah. Jakarta: Gema Insani.

Siswantoro. 2005. Metode Penelitian Sastra: Analisis Psikologis. Surakarta: Muhammadiyah University Press.

Sudikan, Setya Yuwana. Pendekatan interdisipliner, multidisipliner, dan transdisipliner dalam studi sastra. Dalam e-jurnal.fbs. unesa.ac.id. diakses 22 April 2016

Tarnow, Eugen.2003. "How Dreams and memory may be related" 5-2ed. Neuro-psychoanalysis

Wolf, Janet. 1989. The Social Production of Art. New York: New York University Press.

Zhang, Jie. 2005. "Continual-activation theory of dreaming" dalam dynamical psychology. Goertzel.org.

Zulfiqar bin Thahir, Saidna dan Syarifah L.A. 2006. "Tashghir” dalam luvuvikar. blogspot. co.id diakses 12 Mei 2016. 